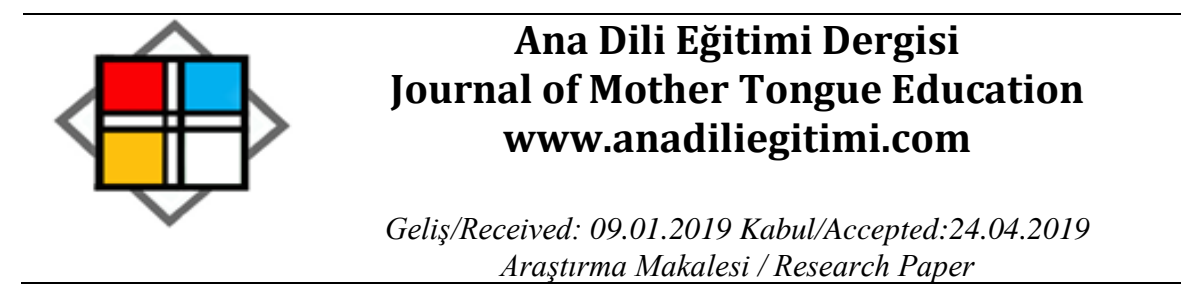

\title{
İkna Etme Tekniğinin Konuşma Tutumu Üzerindeki Etkisi ${ }^{*}$
}

\author{
Muharrem Kürşad YANGiL ${ }^{* *}$ \\ Fulya TOPÇUOĞLU ÜNAL $L^{* * *}$
}

\begin{abstract}
Öz
Illetişim ve konuşma bireyin günlük hayatının her alanında kullandığı bir süreçtir. Konuşma esnasında birey bazen karşısındakini kendisiyle uzlaşma noktasına getirmeye çalışır. İkna, iki kişinin uygun bir çözümde buluşmasıdır. Öğretmenlerin, iletişim alanında başarılı olmaları ve iletişim sürecini iyi bir şekilde oluşturarak ikna etme tekniğini kullanmaları öğrencilerin motive edilmeleri ve başarıya ulaşmalarında önemli yardımcıları olacaktır. Bu nedenle çalışmanın amacı, ikna etme tekniğinin öğretmen adaylarının konuşma tutumuna etkisinin incelenmesidir. Araştırmanın çalışma grubu 2017-2018 öğretim yılında, bir devlet üniversitesi, Eğitim Fakültesi Türkçe ve Sosyal Bilimler Eğitimi Bölümü, Sözlü Anlatım dersini alan toplam 65 öğretmen adayından oluşmaktadır. Araştırma sürecinde, ikna etme tekniğiyle oluşturulan 6 haftalık ders planı uygulanmıştır. Zayıf deneysel desende tasarlanan araştırmada tek grup öntest-sontest desen kullanılmıştır. Veriler bağımlı gruplar t-testi ile analiz edilmiştir. Yapılan analizler sonucunda ikna etme tekniğiyle oluşturulmuş dersin konuşma tutumunu olumlu yönde etkilediği tespit edilmiştir. Ancak ikna etme tekniğinin konuşma tutumu üzerinde cinsiyete göre anlamlı bir farklılık oluşturmadığı sonucuna ulaşılmıştır.
\end{abstract}

Anahtar Kelimeler: İletişim, konuşma, ikna etme tekniği, tutum, eğitim

\section{Effect of Persuasion on Speaking Attitude}

\begin{abstract}
Speaking is a process which people use in every aspect of their daily life. During the conversation, the individual sometimes tries to bring the opposite party to the point of reconciliation in an intellectual sense. Persuasion means that two people meet at a reasonable solution. Teachers should be successful in communication skills and using persuasion technique by well-structured communication procedure will be important helpers in motivation. For this reason, the aim of the study is to examine the effect of persuasion technique on the speaking attitudes of pre-service teachers. The study group consisted of a total of 65 teacher candidates who attended a public university, Faculty of Education Turkish and Social Sciences Education Department, Oral Expression course in 2017-2018 academic year. In the research process, a 6-weeks lesson plan was applied by the persuasion technique. A single group pretest-posttest design was used in the weak experimental design. In the analysis, data-dependent groups were analysed by t-test. As a result of the analyses made, it has been determined that the course created by the persuasion technique
\end{abstract}

\footnotetext{
* Bu çalışma 18-22 Nisan 2018 tarihleri arasında Antalya'da yapılan Uluslararası Eğitim Bilimleri Kongresi'nde sözlü bildiri olarak sunulmuştur

** Dr. Öğr. Üye., Kütahya Dumlupınar Üniversitesi, Eğitim Fakültesi, Türkçe ve Sosyal Bilimler Eğitimi Bölümü, Kütahya, mkursad.yangil@dpu.edu.tr, ORCID: 0000-0001-8110-7325

*** Doç. Dr., Kütahya Dumlupınar Üniversitesi, Eğitim Fakültesi, Türkçe ve Sosyal Bilimler Eğitimi Bölümü, Kütahya, fulyatopcuoglu@gmail.com, ORCID: 0000-0003-3981-9841
} 
affects the speaking skill positively. However there is no meaningful difference in speaking attitude according to gender.

Keywords: Communication, speaking, persuasion technique, attitude, education

\section{Giriş}

Toplumsal bir varlık olan insanoğlunun evrende kendini ifade etmesinin temel aracı iletişim kurabilme yeteneğine sahip olmasıdır. Iletişim insanların birbirlerini etkileme ve birbirlerinden etkilenme yoludur (Krauss ve Fussell, 1996: 655). Bu nedenle birey, hayatın hemen hemen her alanında ve platformunda iletişim becerisini ustalıkla kullanmak zorundadır.

Konuşma iletişimin sözlü olarak cereyan etmesidir. Bu iletişimin bireyler arasında ya da birey toplum arasında gerçekleşmesi şeklinde olabilir. Duyguların ve düşüncelerin kelimelerle, doğru, anlaşılabilir, nitelikli bir şekilde aktarılabilmesi için konuşma ile ilgili özelliklerin kişinin davranışa dönüştürülerek özümsenmesi gerekmektedir. Bu aşamaya gelebilmek için ise eğitim öğretimin ilk kademesinden son kademesine kadar uygun çalışmalarla bu becerinin gelişmesi desteklenmelidir.

İletişim alanında yapılan çalışmalar incelendiğinde iletişimin temel amacının alıcı üzerinde kaynağın amacına uygun olarak belirli bir etki yaratmak olduğu dile getirilmektedir. Bu etki bir anlamda alıcının ve kaynağın iletişim sürecinde ortak bir noktada buluşmaları şeklinde de ifade edilebilir. Bir anlamda kaynağın alıcıyı amacıyla örtüştürmesi yani ikna etmesidir. İkna etme, iletişimin önemli bileşenlerinden biri olarak görülmektedir. Öyle ki iletişim sürecindeki amacın karşısındakini etkileme hatta ikna etme olduğu bile varsayılabilir. İletişimin yani konuşmanın gerçekleştiği hemen her durum ve ortamda bireyler birbirlerini farklı konular hakkında ikna etme çabasındadırlar. Bu ikna etme, ifade edilenin gerçekliğine ikna, muhatabın hareketlerini değiştirmeye ikna yahut başka bir hususta karşısındaki kişiyi ikna etme şeklinde gerçekleşebilir. Çünkü iletişimde ikna etmek iletişimin ortak ve önemli bir amacıdır (Yüksel, 1994: 4).

İkna, kişinin karşısındakini bir konuya inandırması olarak tanımlanmaktadır. İknayla, dil becerileri kullanılarak başkalarının düşünce, tutum ve davranışları değiştirilir. Kobu (1975: 40) ikna etme sürecinin dört bileşeni olduğunu belirtir. Bunlar:

1. İkna etmeye çalışan kişi

2. İkna edilecek kişi

3. İkna edenin fikirleri

4. İkna edilenin fikirleri.

Bu sürecin amacı ikna edilecek kişinin bir konu hakkında sahip olduğu fikirleri başkaları ile değiştirmektir. Aristoteles (2013: 38) ikna etmeyi üç temel unsura bağlar; birincisi konuşmacının karakteri, ikincisi dinleyicinin iknaya hazır hâle getirilmesi ve üçüncüsü, konuşan kişinin sunduğu 


\section{İkna Etme Tekniğinin Konuşma Tutumu Üzerindeki Etkisi}

kanıtlardır. Aristo, bu anlatılanları özetleyerek kaynak, mesaj, izleyenin duyguları ve ayrıca konuşmacının kontrolü dışında kalan olgular ve olaylar olarak sıralamıştır.

Bu bağlamda ikna etme üzerine kurulu olan iletişim, bir kişi, fikir ya da olaya dair duygu, davranış ve düşünce farklıığı meydana getirmek amacıyla yapılan iletişim şeklinde tanımlanabilir (Lord, 1997: 253). Okur, Göçen ve Süğümlü (2013) sıradan iletişim ile ikna etmeye dayalı iletişimin farkının hedeflenen noktaya varmak olduğunu, ikna edici iletişim esnasında kullanılan en iyi aracın dil olduğunu, çünkü diğer iletişim türlerinin aksine ikna edici iletişimde ne söylendiğinden ziyade nasıl söylediğinin önemli olduğunu vurgulamaktadırlar.

Bireyin diğer bir kişinin isteklerine evet demesini sağlayan nedenler, yani ikna tekniklerinin temellerini oluşturan çeşitli psikolojik unsurlar bulunmaktadır. Bunlar; karşııkta bulunma, tutarlılık, toplumsal kanıt, sevgi, otorite, kıtlık, karşıtlık, uzlaşma olarak karşımıza çıkmaktadır. Cialdini, Hogan ve Rinke'nin psikolojik temellere dayandırdığı bu ilkeler, etkileme ve ikna etmede kullanılan pek çok tekniğin temelini oluşturmaktadır. (Akt. Deniz, 2007: 41).

Hogan (2007), Hogan ve Speakman (2007), ikna edici iletişimle ilgili ikna tekniklerine yönelik (sesinizi dikkat çekecek şekilde kullanın, vurgu ve tonlamayı etkili biçimde kullanın, empati kurun, sonuca odaklanarak bunu kafanızda canlandırın, tutarlı olun ....gibi) 59 maddeyi öneri üslubu şeklinde tanıtmışlardır. Bununla birlikte Hale ve Whitlam (1997, s.219-223), Rocha (2003; akt. Karadogon, 2003, s.127) tarafından uygulama örnekleriyle birlikte sunulan ikna teknikleri de (mesajlarınızı ve anahtar ifadelerinizi belirli aralıklarla tekrar edin; kazanacakları şeyler konusunda karsınızdaki kişilerin olumlu hayaller kurmalarını sağlayın; konuyla ilgili kişisel düşüncelerinizi, ilginizi, tecrübelerinizi anlatın... gibi) 10 maddeyle ifade etmişlerdir (Akt. Deniz, 2007: 41-46).

Demirtaş (2004: 19) ise alandaki literatür çalışmalarıyla etkileri ispatlanmış, meslek hayatında olduğu gibi günlük hayatta da en çok yer bulan dokuz temel ikna tekniği olduğundan bahsetmektedir. Bu teknikler; önce küçük sonra büyük rica tekniği, önce büyük sonra küçük rica tekniği, gitgide artan ricalar tekniği, sadece o değil veya satışı tatlandırma tekniği, evet- evet tekniği, acaba değil hangi tekniği, soruya soruyla yanıt verme tekniği, yer etme tekniği, borca sokma tekniği olarak sıralanmaktadır.

Illetişimde başarılı olmak isteyen bireylerin ikna etme tekniğini doğru ve uygun bir şekilde kullanmaları gerekmektedir. Çünkü paylaşımın önemli bir bileşeni olan iletişimin sağlıklı bir şekilde gerçekleşmesi başarıyı beraberinde getirecektir. Birey şayet ikna etme tekniklerini bilirse karşısındaki kişinin fikirlerini aksi yönde bile olsa değiştirip kendi tarafına yönlendirebilecektir. İkna etmede amaç dinleyicilerin bir konudaki düşüncelerini etkileyip konuşulan konudaki fikirlerin benimsenmesini ve kabul görmesini sağlamaktır. 
Illetişim sürecinde yer alan kaynak-ileti (mesaj) -kanal-alıcı ve dönüt temel ögeleri ikna etme sürecinde de yer alır. Kaynak, bireyler arasında gerçekleşen iletişimi başlatan ve mesajı alıcıya gönderen kişidir. İletişim sürecinin en önemli ögesi olan kaynak hem iletişimi başlatması hem de karşısındakinin tutum ve davranışlarını değiştirebileceği için başat role sahiptir. Mesaj, kaynak tarafından üretilen uyaranlardır. Bu uyaranlar dilsel, görsel, işitsel ögelerle birlikte dil dışı kodlamaların da içinde bulunduğu birçok unsurun bileşiminden oluşur. Kanal, gönderilen iletiyi hedefe ulaştıran araçtır. Bu araç iletimde kullanılan her şeyden oluşabilir. Alıcı, gönderilen mesajın hedefi olan kişidir. Eğer alıcı dönüt verirse kaynak olarak da iletişimde yer alabilir. Dönüt ise gönderilen ileti sonrası alıcının göstermiş olduğu tepkidir.

Kaynak eğer ikna etmek istiyorsa birincil olarak amacını net bir şekilde belirlemelidir. Bunun için alıcıya hangi mesajları vereceğini tasarlaması ve bunları düzenlemesi gerekmektedir. Bu aşamadan sonra iletisini güçlendirecek bilimsel, duygusal ve ahlaki verilerini de belirlediği amaca göre şekillendirmelidir. Sonrasında iletinin sunumu gelmektedir. Bunun için kaynağın, mesajı kodlama becerisi ön plana çıkmaktadır. Bireyler arası iletişimde mesaj daha çok sözlü ve sözsüz iletişim ögeleriyle kodlanır (Deniz, 2007: 23).

Konuşan kişinin, grubun, kurumun ya da toplumun saygın ve güvenilir olması mesajı kodlayan ve gönderenin kaynak olması sebebiyle azami önem taşımaktadır. Çünkü dinleyici ya da ikna edilecek kişi kaynağın kim olduğuyla inanılılık dikkate alındığında yakından ilgilidir. Mesaj, sözel ve görsel çeşitli şekillerde olabilmektedir. Yani kaynağın dinleyiciye vermek istediği konu, duygu ve düşünceler, davranışlar yahut tutumların kodlanmış haline mesaj demek mümkündür. Illetilecek mesajın ne olduğu ikna etme sürecinde fazlasıyla önem taşımaktadır. Çünkü iknayı temellendirecek asıl fikirler mesajla verilmektedir. Bu mesajları ise fiziksel olarak kanal ile iletiriz. Kanalın mesaj verilirken farklı şekillerde olması mesajın doğru algılanmasında da çeşitlenmeler yaratabilir. Alıcı ise ikna sürecindeki hedef olduğu için önem arz etmektedir.

İkna, aslında bireyleri önceden bilmedikleri ya da dile getirmedikleri bir fikre doğru yönlendirmeyi temele alır. Bahsi geçen yönlendirme zor kullanarak, yalanla ya da ısrarla yapıımaz. Tam tersine, iyi bir ön çalışma ve organizasyonu, deliller oluşturmayı ve bütün bunları üslubunca aktarmayı lüzumlu kılar. Bunun sonucunda ikna, bir öğrenme sürecine evrilir (Deniz, 2007: 48).

İkna etme tekniğinde iletişim becerileriyle, diğerlerinin konu hakkındaki fikirleri, davranışları ve tutumları değiştirilir. Eğitim açısından ikna edici iletişimin amacı, öğrencileri ikna ederek onları geleceğe hazırlamaktır. Öğretmenler, işleri gereği eğitimin temeli olan istendik davranış değiştirme sürecinde, ikna etme yöntemini en çok ve efektif kullanan meslek grubunun üyeleridir (Jamieson, 1996: 


\section{İkna Etme Tekniğinin Konuşma Tutumu Üzerindeki Etkisi}

4'den aktaran Türkkan, 2000: 18). Dil ve iletişim becerilerinde başarılı olan öğretmenler bu becerilerinden dolayı mesleklerinde daha üretkendirler.

İkna bilhassa konuşma becerisi etkinliklerinin dikkate değer bir ögesidir. Bireylerin konuşma eğitimi aldıktan sonra daha verimli ve daha etkili bir iletişim kurmaları beklenir. Verimin ve başarının kıstaslarından biri de ikna etme tekniğindeki yeterliliğidir (Şahbaz ve Çekici, 2012: 2378).

Konuşmacının ikna edeceği alıcıyı tanıması da ikna sürecinde önemli rol oynamaktadır. Çünkü alıcıyı iyi tanıması konuşmasını yönlendirip ikna etme sürecinde gereken değişiklikleri yapması noktasında kaynağa fayda sağlayıp fark yaratmasına vesile olacaktır.

İkna etme tekniği uygulanırken düşünceleri destekleyen kaynaklara ulaşmak, delilleri güvenilir bir şekilde sunmak, nicel verilere başvurmak, iletişim sürecinde ses ve beden dilini etkili ve yerinde kullanmak gerekmektedir. Tekniğin sınıf içerisindeki uygulamasında ise öğrencilerin ya da oluşturulan grupların verilen konu üzerinde farklı düşünceleri benimseyip diğerlerini savundukları düşünceler hususunda ikna etmeleri beklenmektedir. Öğrencilere tekniğe başlamadan önce süre verilmeli, savundukları fikirleri destekleyecek nitelikte kaynaklara ulaşmaları sağlanmalıdır.

Bireyin bir fikre olan tutumunu değiştirmek için ikna etme tekniğinden faydalanılmaktadır. Çünkü ikna; mevcut davranış ve tutumların değiştirilmesi yoluyla yeni davranış ve tutumların oluşturulması sürecidir. Türkkan (2000: 21) iknanın amacının, tutumları, inançları ve davranışları değiştirmek olduğunu belirtmiştir.

Tutum bireyin belli bir konu, obje ya da fikir hakkındaki duygularını, düşüncelerini ve davranışlarını etkileyen eğilimdir. Gözle görülmeyen tutumu davranışlarda yansıma olarak tespit edebilmek mümkündür. Bireylerin davranışlarının çıkış noktası tutumdur. Yani tutumda yaşanan bir değişiklik davranış değişikliğini de beraberinde getirecektir. Tutum, bireyin bir nesne, bir olay, bir olgu ya da bir fikirle ilgili eğilimleri olarak tanımlanabilir (Tavşancıl, 2002: 65; Yüksel, 1994: 15).

Hovland, bireylerdeki tutumların sonradan öğrenildiğini belirtir ve ikna etme ile ilgili çalışmalarını öğrenme kuramına dayalı olarak sürdürür. Bu sebeple de eğer ki tutumlar öğrenme yoluyla edinildiyse yine aynı mantıkla, öğrenmeyle değiştirilebileceğini savunmaktadır. (Demirtaş, 2004: 75).

Günlük etkileşimler, konuşma, dinleme ve beden dili aracılığıyla gerçekleşir. İkna edici iletişimde tutum değiştirmek için kullanılan temel beceri ise konuşma becerisidir. Konuşma becerisi kişinin kendini ifade etmesiyle ilişkili olduğu için iknaya ve tutum değiştirmeyle doğrudan ilgilidir. İnançları, tutumları, niyetleri veya davranışları üzerinde bir etki oluşturma olasılığı olmayan konuşma olamaz (Deniz, 2007: 16). Bu sebeple konuşma tutumu önem kazanmaktadır. 
Konuşmada başlıca dikkat çeken nokta, toplumsal ilişkiler ve konuşmanın iletişimdeki rolüdür. Konuşma sürecinde bireyin değer yargıları ve hayata bakış açısı şekillenir ve karşısına çıkan durumlarla ilgili bir tutum geliştirmeye başlar. Tutum, kişinin içinde bulunduğu sosyal, ekonomik ve psikolojik ortamın ürünü olduğu ve aile yapısı, eğitim, din, sosyal çevre vb. unsurlar tutumları şekillendirdiği için konuşma tutumu büyük önem taşımaktadır (Usal ve Kuşluvan, 1999, s.128). Bu doğrultuda konuşmaya yönelik olumlu bir tutum bireye sosyal hayatında ve öğretim hayatında başarı sağlar. Bunun yanında kişinin özgüven kazanması ve çevresiyle başarılı bir iletişim kurabilmesi becerisi de kazandırır (Karahan, 2015: 39).

Öğrenmenin önemli bileşenlerinden birisi öğretmendir. Bu nedenle öğretmenlerin konuşma becerisini etkili bir şekilde kullanmaları gerekmektedir. Bireylerin gelecekteki hayatlarını daha nitelikli hale getirebilmek için bireylere kazandırılması gereken önemli becerilerden birisi konuşma becerisi olduğu için konuşma ve konuşma tutumu önem kazanmaktadır.

Konuşma tutumunun olumlu bir şekilde gelişmesi günlük hayattan iş hayatına kadar çok geniş bir ölçekte bireye fayda sağlamaktadır. Özellikle günümüzde bireyleri yetiştiren öğretmenlerin meslek hayatlarında diplomayla değil, konuşma yani iletişim becerileriyle başarı sağlayacakları muhakkaktır. Bu sebeple öğretmen adaylarının konuşma tutumlarının olumlu yönde gelişmesi önem kazanmaktadır. Çünkü her gün yepyeni bilgilerle öğrencilerin karşısına çıkmakta ve onları yeni bilgilere ikna etmek zorunda kalmaktadırlar.

Bireylerin eğitim hayatları boyunca başarılı olmaları onların tüm yaşamlarını büyük ölçüde değiştireceği için ders aldıkları öğretmenlerin ikna etme tekniğinde başarılı olmaları büyük önem arz etmektedir. Öğrencinin motivasyonunu sağlamak ve öğrenciyi hayata hazırlamak için ikna etmek eğitimcinin görevidir. İkna etme eğitim sürecinde başarıya ulaşmada anahtar rolü taşımaktadır. Bütün bunlar dikkate alındığında eğitimcinin ikna tekniğini en iyi şekilde icra etmesi gerekmektedir (Cyndie, 2001: 4).

Deniz (2007: 48-50) araştırmasında ülkemizde bir etkili iletişim becerisi olan ikna üzerine yapılan çalışmaların pek yaygın olmadığını, bunun eğitime yansıtılmasına yönelik araştırmaların ise yok denecek kadar az olduğunu ifade etmiştir. Bu açıdan önem kazanan çalışmamız öğretmenlerin davranışlarının ikna teknikleriyle örtüşmesi sebebiyle öğretmenlerin ve öğretmen olma yolunda olan öğretmen adaylarının ikna tekniğini başarılı bir şekilde kullanmaları gerektiğini gözler önüne sermektedir.

İkna etme tekniği kullanılarak gerçekleştirilen iletişim sürecinde konuşma tutumlarını olumlu yönde değiştirmek için, verilen bilginin karşı tarafta gerçekleştireceği davranış ve tutum değişikliklerinin istenen yönde olacağı varsayılmaktadır. 
Bu sebeple yukarıdaki bilgiler doğrultusunda öğretmen adaylarının konuşma tutumlarının ikna etme tekniği ile uygulanacak dersler sonrasındaki durumu çalışmanın konusunu oluşturmaktadır.

Araştırmada, ikna etme tekniğinin öğretmen adaylarının konuşma tutumuna etkisi ve cinsiyete göre farkının incelenmesi amaçlanmıştır.

\section{Yöntem}

\section{Araştırmanın Modeli}

Araştırma deneysel desende oluşturulmuştur. Deneysel desen "model" araştırmacının kontrolü altında değişkenler arasındakinden sonuç ilişkilerini keşfetmek için gözlenmek istenen verilerin üretildiği araştırma alanıdır (Büyüköztürk, 2001; Karasar, 2005).

Deneysel desenlerden zayıf deneysel desende tasarlanan araştırmada tek grup öntestsontest desen kullanılmıştır. Bu desende işlemin etkisi tek grup üzerinde yapılan çalışma ile test edilir.

Tablo 1. Deneysel Desen Işslem Tablosu

\begin{tabular}{cccc}
\hline Grup & Öntest & İşlem & Sontest \\
\hline $\mathrm{G}$ & $\mathrm{O}_{1}$ & $\mathrm{X}$ & $\mathrm{O}_{2}$
\end{tabular}

\section{Araştırma grubu}

Araştırmanın çalışma grubu 2017-2018 öğretim yılında, bir devlet üniversitesinin Eğitim Fakültesi Türkçe ve Sosyal Bilimler Eğitimi Bölümü, Sosyal Bilgiler Ana Bilim Dalı Sözlü Anlatım dersini alan toplam 75 öğretmen adayından oluşmaktadır. Ancak verilerin toplanmasında ulaşılan katılımcı sayısı 65 olduğu için analizler 65 katııımının verileri üzerinden yapılmıştır.

Tablo 2. Katılımcıların Cinsiyetlere Göre Dağılımı

\begin{tabular}{ccc}
\hline Cinsiyet & Sıklık (f) & Yüzde (\%) \\
\hline Erkek & 25 & 38.5 \\
Kadın & 40 & 61.5 \\
Toplam & 65 & 100.0
\end{tabular}

Bu 65 katılımcının 25’i erkek 40’ kadındır. Katılımcıların cinsiyetlerine göre sıklığı yukarıdaki tabloda verilmiştir.

\section{Veri Toplama Araçları}

Araştırmanın verileri "Konuşma Becerisi Tutum Ölçeği" ile toplanmıştır. Verilerin toplanmasında ölçek ön-test son-test olarak gruba uygulanmıştır. Topçuoğlu Ünal ve Özer (2017) tarafından geliştirilen ölçeğin verileri, 2015-2016 eğitim-öğretim yılında eğitim-öğretim yılında 210 
öğrenciden elde edilmiştir. Ölçekte Açımlayıcı faktör analizi uygulanmıştır. Yapılan analizin sonuçlarına göre 2 alt boyuttan oluşan, $5^{\prime} l i$ likert şekilde düzenlenmiş 27 maddeli bir ölçek elde edilmiştir. Ölçeğin güvenirliği için iç tutarlılık çalışması yapılmış ve ölçeğin Cronbach Alfa İç Tutarlılık katsayısı 0.81 olarak hesaplanmıştır. Ölçeğin iç tutarlılık katsayıları; birinci boyutta "Konuşma Becerisine Yönelik illgi ve Sevgi".86, ikinci boyutta "Konuşma Becerisine Karşı Kaygı ve Endişe" .73 olarak bulunmuştur. Analiz sonuçları dikkate alındığında ölçek maddelerinin birbirleriyle tutarlı oldukları ve ölçülmek istenilen tutumu yansıttığı söylenebilir. Analizler sonucunda ölçeğin geçerli ve güvenilir bir ölçek olduğu kanısına varılmıştır.

İşlem

Araştırma sürecinde, Hogan (2007), Hogan ve Speakman (2007)'dan akt. Deniz (2007: 33-34 ve 41-46)' de yer alan ikna etme teknikleri ve ikna basamakları dikkate alınarak oluşturulan 6 haftalık plan hazırlanmış ve öğretmen adayları tarafından uygulanmıştır.

1. Hafta: Konuşma becerisi tutum ölçeği ön test olarak uygulanır. Ölçek sonrası ikna etme tekniği ile ilgili katılımcılara aşağıdaki bilgiler verilip ikna etme tekniğini ve basamaklarını tanımaları sağlanır:

İkna edici iletişim, belli aşamaların izlenmesi sonucunda elde edilmek istenilen amaca ulaşıımasını sağlar. Çünkü işlem sonunda davranış değiştirme esastır. Bireyler arası iletişim dikkate alındığında ikna basamakları "dikkat, ilgi, istek ve davranış" olmak üzere dört aşamada gerçekleştirilmektedir:

1. Dikkat çekme: İkna etme için ilk aşama dikkat çekmeyle başlar. Ikna edilecek kişinin ikna edileceği konuya dair farklı görüş ve bilgiler verilerek dikkatini çekmek suretiyle yapılır. Genel olarak birdenbire yapılan uyarıcı değişiklikleridir. Başlangıçta yapılabildiği gibi gerek duyulduğu herhangi bir zamanda da başvurulabilir.

2. İlgi: Aktarılmak istenen mesajın, alııının ilgisini çekecek bir mesaj olduğu vurgulanmalıdır. Bu vurgunun ardından da mesajın net bir şekilde verildiğinden ve alııının bu mesajı net anladığından emin olunmalıdır. Buradaki en önemli unsur alıcının ihtiyaçlarına göre bir mesaj sunmaktır. Bu intiyaçların giderilmesinde elde edeceklerinin söylenmesi de yine bu basamağı başarıya ulaştıracak unsurlardandır.

3. İstek: Alıcının farklı uyaranlarla dikkati çekilip iletilen mesajın ilgi çekici bir mesaj olduğu alıcı tarafından kabul edildikten sonra istek kendiliğinden uyanacaktır. Buradaki en önemli unsur mesajın iletilirken sunulduğu şekildir. Mesajı veren kaynak, alıcıyla duygularının, bilgilerinin ve isteklerinin ortaklığını hissettirirse alıcı kendini daha yakın ve iyi hissedecektir. Bu vesileyle de direnç 


\section{İkna Etme Tekniğinin Konuşma Tutumu Üzerindeki Etkisi}

göstermek yerine kabul etme eğilimi gösterecek ve harekete geçmek için kendinde çok daha fazla güç bulacaktır.

4. Hareket (Davranış): İkna etmenin beklenen sonucu olan hareket eylemi, alıcının ikna sonrası göstereceği davranıştır. Alıcı istenilen yönde davranış gösterdiyse ikna etme başarılı olunmuştur denilebilir. Ayrıca bu hareket zorla, korkutmayla değil de istekle yapılmışsa kalıcılık çok daha üst seviyede olacaktır.

Basamakların işlevlerinin anlatılmasının ardından Hogan (2007), Hogan ve Speakman (2007)'ın (Akt. Deniz, 2007: 41-46), ikna edici iletişimle ilgili ikna tekniklerine yönelik tanıttıkları 59 maddelik öneriler tanıtılmıştır.

Bu açıklamalar sonrasında öğrenciler ve konuşacakları konular belirlenerek araştırma yapmaları ve onlara verilen ikna etme tekniklerini özümsemeleri için bir hafta süre tanınır.

2. Hafta: Televizyonda yayımlanan dizilerin kültürümüze vermiş olduğu zararları anlatacak bir konuşma yapmaları istenir ve dizilerdeki mesajları sorgulamaları sağlanır. Bu esnada dikkat edecekleri ikna tekniklerinin şunlar olduğu belirtilir:

-Ortak düşman, ortak sorun bulun veya oluşturun.

-Net ve kesin ifadeler kullanın.

-Sebep gösterici etkisinden dolayı "çünkü" kelimesini cevap verirken ve soru sorarken sık kullanın.

-Kanıtlarınız kesinliğe dayansın.

-Karşınızdaki kişinin değerleri, ihtiyaçları, tutumları, ilgi alanları, onu motive eden unsurlar, bildikleri vb. hakkında bilgi sahibi olmaya çalışın. Bu, amacınıza giden yolları belirlemeyi sağlayacaktır.

-Sorular yardımıyla karşınızdaki kişinin bakış açılarını, değerlerini ve inançlarını ortaya çıkarmaya çalışın.

3. Hafta: Öğrencilerden öğrenci temsilcisi/öğrenci konseyi seçimine yönelik seçim propaganda konuşması yapmaları istenir. Bu esnada dikkat edecekleri ikna tekniklerinin şunlar olduğu belirtilir:

- Karşınızdaki insanlarla uyum sağlayın.

- Bir hediye vererek ortaklık kurun.

- Kusurlarınızı, hatalarınızı itiraf etmekten çekinmeyin; önerdiğiniz şeyin kusurlarını belirtin.

- Yardımcı ve paylaşımcı olun. 
- Karşınızdakileri iddia ve bilgilerle şaşırtın.

- Alçak gönüllü davranın.

- Karşınızdakilere güven verin.

- Tutarlı olun.

4. Hafta: Öğrencilerden bir arkadaşını, bir konuda bir şeye (örneğin ders çalışmaya, kendisine yeni aldığı kazağı vermeye, sevmediği birileriyle bir araya gelmeye) ikna etmeleri istenir. Bu esnada dikkat edecekleri ikna tekniklerinin şunlar olduğu belirtilir:

- Bir iş, hareket konusunda karşınızdakilerin onayını almanızı sağlayacak sorular, sözde sorular kullanın.

- Az bulunurluk hissi yaratın.

- İsim, rica, teşekkür ve sebep kelimelerini konuşmalarınızda sık kullanın.

-Bir şeyleri doğrudan istemek yerine olasılık, tahmin, tonlama yoluyla rica etme gibi ifadeleri kullanın.

-Yaptığınız iyiliklerle karşınızdaki insanların size borçlu olduklarını hissetmelerini sağlayın.

5. Hafta: Öğrencilerden belirledikleri konuda karşısındakileri ikna edici şekilde konuşmaları istenir. Bu esnada dikkat edecekleri ikna tekniklerinin şunlar olduğu belirtilir:

-Etki gücü yüksek kelimeler (sen, para, kurtarmak, sonuç, sağlık, kolay, aşk, keşif, kanıtlanmış, yeni, güvenlik, garanti vb.) kullanın. Bu kelimelerin özellikle soru kalıpları içeresinde kullanılması daha etkili olur.

-Olumlu sözcükler kullanın.

-i̇nsanlar eğer bir konuyu bilmiyorsa da cümlelerinizi "Sizin de bildiğiniz gibi..." gibi ifadelerle zenginleştirin. Bu, karşınızdaki kişinin size uymasını sağlayacaktır.

-Ses tonunuzu, sesinizi, vurgu ve tonlamanızı konuşmanızın içeriğine uygun olarak ayarlayınız. -Beden dilinizi sözlerinizle uyumlu kullanın.

6. Hafta: Son test uygulaması olarak konuşma becerisi tutum ölçeği uygulanır.

\section{Verilerin Analizi}

Verilerin analizinde istatistik programı kullanılmış ve veriler bağımlı gruplar t-testi ile analiz edilmiştir. 


\section{Bulgular}

Bu bölümde araştırmanın amacı doğrultusunda ikna etme tekniğine dayalı eğitim alan katılımcıların konuşma tutumundaki "ilgi ve sevgi" ile "kaygı ve endişe" ye ilişkin bulgulara yer verilmiştir. Aşağıda Tablo 4'de ikna etme tekniğinin katılımcıların konuşma tutumlarının ilgi ve sevgi boyutuna ilişkin bağımlı gruplar t-testi sonuçları bulunmaktadır.

Tablo 3. Ikna Etme Tekniği Ile Oluşturulmuş Dersin Konuşma Becerisi Tutumu IIgi-Sevgi Düzeylerinin ÖntestSontest Ortalama Puanlarının t-Testi Sonuçları

\begin{tabular}{|c|c|c|c|c|c|c|}
\hline Ölçüm & $\mathbf{N}$ & 0 & $S$ & Sd & $\mathbf{t}$ & $p$ \\
\hline $\begin{array}{c}\text { Öntest } \\
\text { ilgi- sevgi boyutu }\end{array}$ & 65 & 3.97 & .51 & & & \\
\hline $\begin{array}{c}\text { Sontest } \\
\text { ilgi-sevgi boyutu }\end{array}$ & 65 & 4.35 & .33 & 64 & 5.59 & .000 \\
\hline
\end{tabular}

Tablo 3’te görüldüğü gibi ikna etme tekniği ile oluşturulmuş dersin konuşma becerisi tutumu ilgi-sevgi düzeylerinin öntest-sontest ortalama puanlarının t-testi sonuçlarına göre sontest lehine anlamlı bir farklılık bulunmuştur. İkna etme tekniğinin konuşma becerisi tutum ölçeği ilgi-sevgi faktörüne olumlu bir etki yaptığı söylenebilir.

Tablo 4. Ikna Etme Tekniği Ile Oluşturulmuş Dersin Konuşma Becerisi Tutumu Kaygı-Endişe Düzeylerinin ÖntestSontest Ortalama Puanlarının t-Testi Sonuçları

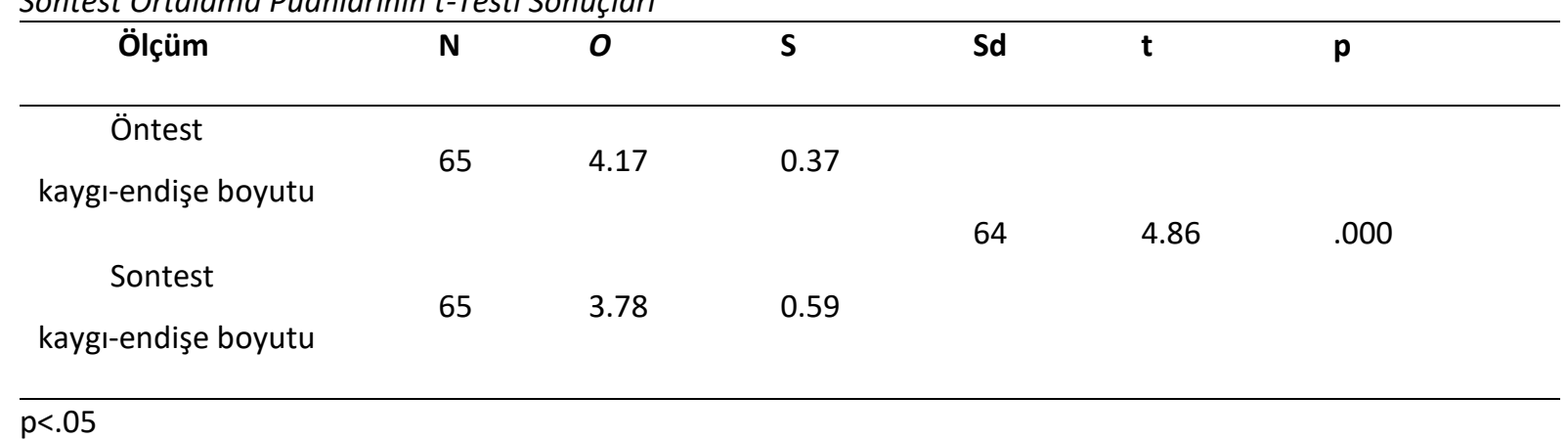

Kaygı-endişe düzeylerinin öntest-sontest ortalama puanlarının t-testi sonuçlarına göre sontest ortalama puanı öntestten daha düşüktür. Buradan da uygulama sonrası kaygı-endişe düzeyinin azaldığı tespit edilmiştir. İkna etme tekniği ile oluşturulmuş dersin konuşma becerisi tutumu kaygıendişe düzeylerinin öntest-sontest ortalama puanlarının t-testi sonuçlarına göre sontest lehine anlamlı bir farklılık bulunmuştur. İkna etme tekniğinin konuşma becerisi tutum ölçeği kaygı-endişe faktörüne olumlu bir etki yaptığı söylenebilir. 
Muharrem Kürşad YANGiL, Fulya TOPÇUOĞLU ÜNAL

Tablo 5. Ikna Etme Tekniği ile Oluşturulmuş Dersin Konuşma Becerisi Tutumu Öntest-Sontest Ortalama Puanlarının t-Testi Sonuçları.

\begin{tabular}{ccccccc}
\hline Ölçüm & $\mathbf{N}$ & $\mathbf{O}$ & $\mathbf{S}$ & $\mathbf{S d}$ & $\mathbf{t}$ & $\mathbf{p}$ \\
\hline Öntest & 65 & 3.92 & .42 & & 64 & 6.75 \\
Sontest & 65 & 4.30 & .30 & & .000
\end{tabular}

$\mathrm{p}<.05$

İkna etme tekniği ile oluşturulmuş dersin konuşma becerisi tutumu öntest-sontest ortalama puanlarının t-testi sonuçlarına göre sontest lehine anlamlı bir farklılık bulunmuştur. İkna etme tekniğinin konuşma becerisi tutumunu olumlu yönde etkilediği sonucuna varılabilir.

Tablo 6. Ikna Etme Tekniği ile Oluşturulmuş Dersin Konuşma Becerisi Tutumu Öntest-Sontest Ortalama Puanlarının Cinsiyete Göre t-Testi Sonuçları

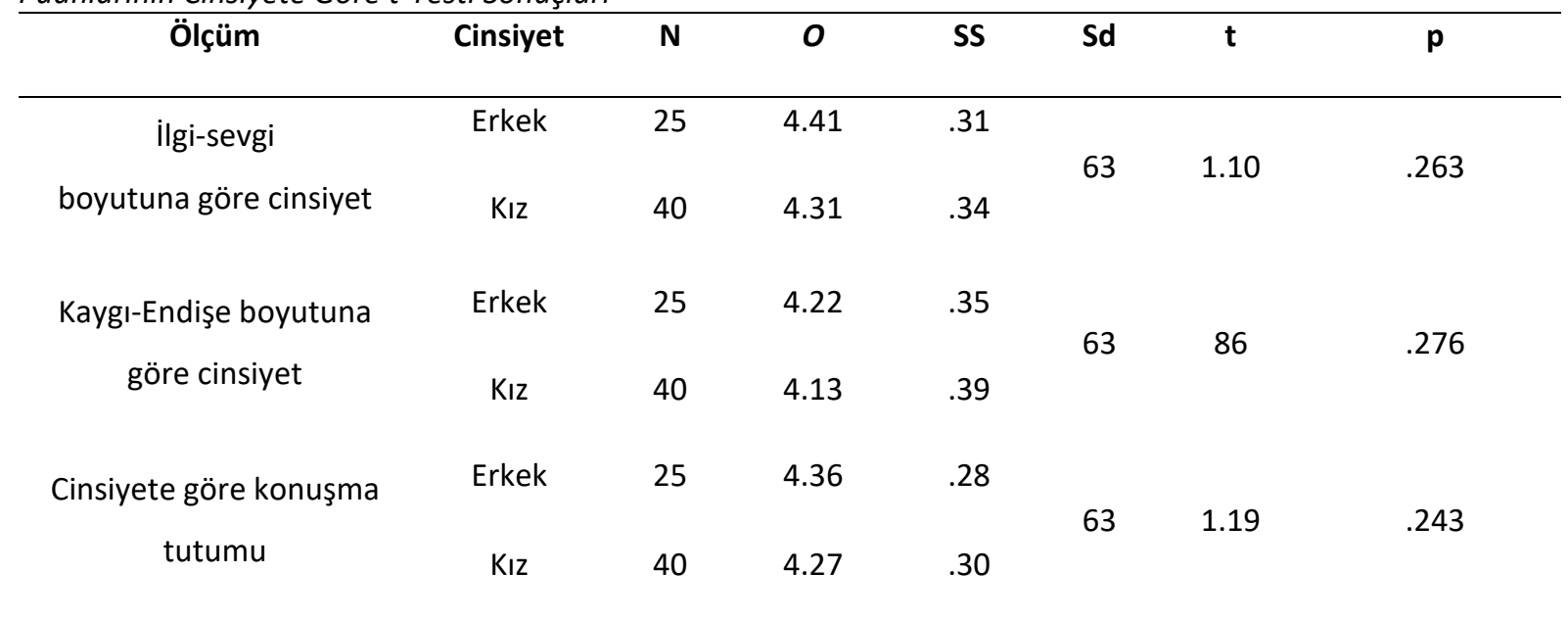

İkna etme tekniği ile oluşturulmuş dersin konuşma becerisi tutumu öntest-sontest ortalama puanlarının cinsiyete göre t-testi sonuçları dikkate alındığında konuşma becerisi tutumunun cinsiyete göre anlamlı bir farklılık yaratmadığı sonucuna ulaşılmıştır.

\section{Tartışma, Sonuç ve Öneriler}

İkna etme tekniğinin öğretmen adaylarının konuşma tutumuna etkisinin incelenmesi amaçlanan çalışmada yapılan analizler sonucunda ikna etme tekniği ile oluşturulmuş dersin konuşma becerisi tutumu olumlu yönde etkilediği sonucuna ulaşılmıştır. Ayrıca araştırmada ikna etme tekniğinin konuşma becerisi tutum ölçeği ilgi-sevgi faktörü ile kaygı-endişe faktörüne de olumlu bir etki yaptığı sonucuna ulaşılmıştır.

Ayan, Katrancı ve Melanlığlu (2014) yaptıkları çalışmada konuşma becerisinin öğretmen adaylarının en çok zorlandıkları dil becerisi olduğunu ifade etmişlerdir. Konuşma günlük hayatta en çok kullanılan dil becerisi olmasına rağmen en zorlanılan becerilerden biridir. Özellikle topluluk karşısında konuşma esnasında kaygı düzeyinin artması, bireyin heyecanına yenik düşmesi, entelektüel altyapısının yetersiz oluşu, topluluğun konuşana bakış açısı vb. gibi sebeplerle konuşma tutumu olumsuz yönde 


\section{İkna Etme Tekniğinin Konuşma Tutumu Üzerindeki Etkisi}

etkilenmektedir. Bu açıdan bakıldığında konuşanın bu kaygısının üzerine gitmesi ve olumsuz olarak algılanan bu durumu olumlu yönde değiştirmesi hem kendi çabası hem de eğitim kurumlarındaki öğretmenlerin desteği sonucunda geliştirmesi beklenmektedir. Bu bakımdan ikna etme tekniği ile hazırlanmış derslerin öğretmen adayları için uygulanması ve öğretmen adaylarının konuşma tutumları üzerindeki olumlu etkisi önem kazanmaktadır.

Illetişimde önemli bir yere sahip olan ikna etme tekniğine hassasiyet gösterilmesi, öğrencilerin diğer becerilerinin de sağlıklı bir şekilde ilerlemesine fayda sağlayacaktır. Sonuçta özgüveni yüksek, iletişimde başarılı kişiler olarak yetişmelerine yol açacaktır. Kurudayıoğlu ve Yılmaz (2014) yaptıkları çalışmada öğrencilerin ikna etme tekniklerini ve türlerini bilmesi gerektiğini, çünkü öğrencilerin pek çok ikna çeşidiyle yüzleştiklerini belirtmektedirler. Bu da çalışmamızı destekler niteliktedir.

Yıldız Demirtaş ve Sucuoğlu (2011) yaptıkları çalışmada çocukların iş birlikli çalışma esnasında katılımda bulunmak istemeyen arkadaşları olduğunda sergiledikleri davranışların dağıımını incelemişler ve \%33.3 oranında arkadaşlarını ikna etmeye çalıştıklarını tespit etmişlerdir. Araştırmacılar, çocukların iş birlikli çalışma esnasında birbirlerinin fikirlerini reddettiklerinde sergiledikleri davranışları incelediklerinde ise konuşup birbirlerini ikna etmeye çalışarak konu üzerinde tartıştıklarını ortaya koymuşlardır. Yıldız Demirtaş ve Sucuoğlu (2011) yapmış oldukları diğer bir çalışmada ise "çocukların kendi kendini görev konusunda ikna etme" oranını \%18.42 olarak tespit etmişlerdir. Bu durum ise iknanın bireyin kendisine de yönelik bir süreç olduğunu ortaya koymaktadır. Bu durumlar dikkate alındığında iknanın her yaş ve öğretim kademesinde önemini yansıtması açısından yapılan araştırmalar çalışmamızla örtüşmektedir.

Kayabaşı ve Akcengiz (2014) yaptıkları çalışmada öğretmen adaylarının zihinsel, davranışsal ve duyuşsal iletişim becerileriyle cinsiyetleri arasında anlamlı bir farklılık bulunmadığı sonucuna ulaşmışlardır. Aynı şekilde Özkan ve Kınay (2015) öğretmen adaylarının konuşma kaygılarının inceledikleri çalışmalarında cinsiyetin konuşma kaygısı üzerinde anlamlı bir etki ortaya çıkarmadığı sonucuna ulaşmışlardır. Bu sonuçlar çalışmamızda ikna etme tekniğinin konuşma tutumu üzerindeki etkisinde cinsiyetin anlamlı bir farklılık yaratmadığı sonucuyla örtüşmektedir. Fakat Mısırlı (2008) 'nın yaptığı araştırma ise, çalışmamızın tersine cinsiyet farklııklarının iletişimi engelleyen etkenlerden olduğu sonucuna ulaşmıştır. Ayrıca çalışmamızın sonucuyla örtüşmeyen başka bir sonuç da Deniz (2007: 189)'in yaptığı çalışmada ikna beceri ve tekniklerini uygulama konusunda bayan öğretmenlerin, erkek meslektaşlarına göre daha ileri bir düzeyde olduğu yani cinsiyete göre anlamlı bir fark olmasıdır.

Yaptıkları çalışmalarında yaratıcı drama etkinliklerinin Türkçe öğretmen adaylarının konuşma becerilerine etkisini inceleyen Aykaç ve Çetinkaya (2013) yaptıkları yaratıcı drama uygulaması etkinliklerinin Türkçe öğretmeni adaylarının konuşma becerilerini olumlu yönde geliştirdiği ve konuşma 
sürelerinin uzadığı sonucuna ulaşmışlardır. Maden'in (2011) rol kartlarının konuşma eğitimindeki başarı ve tutum üzerindeki etkisini incelediği çalışmasında, rol kartları ile işlenen dersin konuşma becerisi bağlamında geleneksel öğretime göre daha etkili olduğunu tespit etmiştir. Bu çalışmalardan hareketle, konuşma becerisi ve konuşma tutumunun geliştirilmesinde dersin yöntem ve tekniklerle zenginleştirilmesinin olumlu yönde etkilediği görülmektedir. Bu bağlamda yapılan çalışmalar, çalışmamızı destekler niteliktedir.

Konuşma tutumunun ikna tekniğiyle geliştirilmesi amacıyla yapılan araştırmamız sonucunda aşağıdaki öneriler getirilebilir:

1- Konuşma becerisinin ve tutumunun geliştirilmesi için konuşma becerisi ile ilgili yöntem ve tekniklerle oluşturulan yeni deneysel çalışmalar yapılabilir.

2- Konuşma becerisinin ve tutumunun geliştirilmesi için konuşma becerisi ile ilgili etkinliklere daha fazla yer ayrılabilir.

3- Deneysel çalışmalar yanında çalışmalar karma desende şekillendirilip öğrenci ve öğretmen görüşleri alınabilir. Böylelikle eksiklikler, sorunlar ve yapılması gerekenler için elde edilen görüşlerle yol haritası oluşturulup bu doğrultuda çalışmalar yapılabilir.

4- Öğretmen adaylarının konuşma becerisini geliştirici faaliyetlerden azami surette yararlanmaları gerekmektedir. Çünkü ikna edici iletişim eğitim ortamında daha çok bu beceriye bağlıdır.

5- İkna etme teknikleri konuşmanın yöntem ve tekniklerini doğru şekilde uygulamaya dayanmaktadır. Öğretmen adaylarının öğretmenlik yaparken öğrencilerini ikna edecek teknikleri iyi bilmeleri ve etkili bir şekilde kullanmaları sağlanmalıdır.

6- Eğitim Fakülteleri bünyesinde yer alan Sözlü Anlatım, Etkili İletişim Becerileri, Konuşma Eğitimi gibi derslerin içeriğinde ikna etme teknikleri daha detaylı verilmesi ve öğretmen adaylarının bunları daha verimli kullanmaları sağlanmalıdır.

\section{Kaynaklar}

Aristoteles. (2013). Retorik. (M. H. Doğan, Çev.). İstanbul: Yapı Kredi Yayınları.

Ayan, S., Katrancı, M. ve Melanlıoğlu, D. (2014). Awareness level of teacher candidates' in terms of their Turkish language sufficiency: A qualitative research. International Journal of Academic Research Part B, 6 (29), 137-143.

Aykaç, M. ve Çetinkaya, G. (2013). Yaratıcı drama etkinliklerinin Türkçe öğretmen adaylarının konuşma becerilerine etkisi, Turkish Studies, 8 (9), 671-682.

Büyüköztürk, Ş. (2001). Deneysel desenler. Ankara: Pegem A Yayıncılık.

Cyndie, H. (2001). Persuasion and its role in meeting educational goals. Theory into Practice. 40 (4), 268-277. 
Demirtaş, H. A. (2004). Temel ikna teknikleri: tutum oluşturma ve tutum değiştirme süreçlerindeki etkilerinin altında yatan nedenleri üzerine bir derleme. Gazi Üniversitesi Iletişim Fakültesi Dergisi, 19, 73-91.

Deniz, K. (2007). Ilköğretim ikinci kademede konuşma ve dinleme yoluyla öğrencileri ikna üzerine bir araştırma. Yayımlanmamış doktora tezi, Gazi Üniversitesi Eğitim Bilimleri Enstitüsü, Ankara.

Karahan, B. (2015). Türkçe öğretmen adaylarının konuşma eğitimine yönelik tutumları (Kars ili örneği), $e-K a f k a s$ Eğitim Araştırmaları Dergisi, 2(1), 38-45.

Karasar, N. (2005). Bilimsel araştırma yöntemi. Ankara: Nobel Yayın Dağıtım.

Kayabaşı, Y. ve Akcengiz, S. A. (2014). Eğitim fakültesinde okuyan öğretmen adaylarının iletişim becerilerinin farklı değişkenler açısından incelenmesi. Gazi Üniversitesi Endüstriyel Sanatlar Eğitim Fakültesi Dergisi, 33, 86104.

Kobu, B. (1975). İkna etme sanatı. Yönetim-Istanbul Üniversitesi İşletme Fakültesi Işletme iktisadı Enstitüsü Dergisi, 1(1), 39-42.

Krausss, R. M. and Fussell, S. R. (1996). Social psychological models of interpersonal communication. In E.T. Higgins \& A. Kruglanski (Eds.), Social Psychology: A Handbook of Basic Principles, (pp. 655-701). New York: Guilford.

Kurudayıŏlu, M. ve Yılmaz, E. (2014). Türkçe öğretmeni adaylarının oluşturdukları ikna edici metinlerin yapı açısından incelenmesi. Okuma Yazma Eğitimi Araştırmaları, 2(1), 12-21.

Lord, C. G. (1997). Social psychology. NY: Harcourt Brace College Publishers.

Maden, S. (2011). Rol kartlarının konuşma eğitimindeki başarı ve tutum üzerine etkisi. Çankırı Karatekin Üniversitesi Sosyal Bilimler Enstitüsü Dergisi, 2 (2), 23-38.

Mısırlı, İ. (2004). Genel ve teknik iletişim. Ankara: Detay Yayıncılık.

Okur, A., Göçen, G. ve Süğümlü, Ü. (2013). İkna edici yazma ve karşılaştırmalı bir araştırma (Avustralya ana dili öğretimi ders materyalleri ve Türkiye örneği). Mustafa Kemal Üniversitesi Sosyal Bilimler Enstitüsü Dergisi, 10 (21), 167-197.

Özkan E. ve Kınay, í. (2015). Öğretmen adaylarının konuşma kaygılarının incelenmesi (Ziya Gökalp eğitim fakültesi örneği). Uluslararası Türkçe Edebiyat Kültür Eğitim Dergisi, 4 (3), 1290-1301. http://dx.doi.org/10.7884/teke.519

Şahbaz, N. K. ve Çekici, Y. E. (2012). Disiplinler arası bir disiplin olarak Türkçe eğitimi. Turkish Studies, 7 (3), $2367-$ 2382. http://dx.doi.org/10.7827/TurkishStudies.3522

Tavşancıl, E. (2002). Tutumların ölçülmesi ve spss ile veri analizi. Ankara: Nobel Yayınları.

Topçuoğlu Ünal, F. ve Özer, D. (2017). Ortaokul öğrencileri için konuşma becerisi tutum ölçeği: geçerlilik ve güvenirlik çalışması. International Journal of Language Academy, 5 (6), 120-131. http://dx.doi.org/10.18033/ijla.3739

Türkkan, R. O. (2000). Ikna ve uzlaşma sanatı. İstanbul: Hayat Yayıncılık.

Usal, A., Kusluvan, Z. (1999). Davranış Bilimleri. İzmir: Barış Yayınları.

Yıldız Demirtaş, V. ve Sucuoğlu, H. (2011). Aktif öğrenme gruplarında usta-acemi çocukların karşılaştıkları sorunlar ve çözüm yolları. Illköğretim Online, 10 (2), 479-492.

Yıldız Demirtaş, V. ve Sucuoğlu, H. (2011). Erken çocukluk döneminde aktif öğrenme gruplarındaki usta ve acemi çocukların grup çalışma süreçleri. Education Sciences, 6 (1), 549-561.

Yüksel, A. H. (1994). Ikna edici iletişim. Eskisehir: Anadolu Üniversitesi Yayınları. 


\section{Extended Abstract \\ Introduction}

Persuasion can occur in the form of the reality of what is expressed, of the interlocutor to change his/her behaviors, or of the person in favor of an opposite idea.

Individuals who want to be successful in terms of communication must use persuasion techniques correctly and appropriately. Communication is an important component of sharing, and successful communication will lead to success accordingly. The aim of the persuasive communication in terms of education is to prepare students for the future.

In order to change the attitudes positively in the communication process using the persuasion technique, it is assumed that the behavior and the attitude changes on the other side effected by the given information will be in the desired direction.

For this reason, in accordance with the above information, the assumption of the study is that the preservice teachers' speaking attitudes change after the courses applied with the persuasion technique.

In the study, it is aimed to investigate the effect of the persuasion technique on pre-service teachers' speaking attitudes.

\section{Method}

The study was conducted in the experimental design. The study group of the research consisted 75 preservice teachers who took Oral Expression course in 2017-2018 academic year. However, since the number of participants involved in the experiment was 65 , the analyses were conducted on the data of 65 participants.

The data of the study were collected with the "Speaking Skill Attitude Scale". In the data collection, the scale was applied to the group as pre-test and post-test. The scale developed by Topçuoğlu Ünal and Özer (2017) is a 5-item Likert-type scale consisting of 2 sub-dimensions and 27 items. The Cronbach Alpha Internal Consistency coefficient of the scale was calculated as 0.81 . Internal consistency coefficients of the scale; in the first dimension "Interest in Speaking Skill" was found as .86; in the second dimension "Anxiety and Concern for Speaking Skill" was found as .73. During the research process, a 6-weeks course plan which was formed by taking the persuasion technique into consideration was prepared and applied. In the data analysis the statistical program was used, and the data were analyzed by the dependent t-test.

\section{Result and Discussion}

A significant difference was found in favor of the post-test between the pre-test $(M=3.97, S D=.51, p=$ $.000)$ and post-test $(M=4.35, S D=.33, p=.000)$ results of the speaking skill attitude interest levels of the course which was structured by the persuasion technique. It can be concluded that the persuasion technique has a positive effect on the interest factor of the speaking skill attitude scale.

A significant difference was found in favor of the post-test between the pre-test $(M=3.78, S D=.59, p=$ $.000)$ and post-test $(M=4.17, S D=.37, p=.000)$ results of the speaking skill attitude anxiety-concern levels of the course which was formed by the persuasion technique. It can be concluded that the persuasion technique has a positive effect on the anxiety-concern factor of the speaking skill attitude scale.

A significant difference was found in favor of the post-test between the pre-test $(M=3.92, S D=.42, p=$ $.000)$ and post-test $(M=4.30, S D=.30, p=.000)$ results of the speaking skill attitude of the course which was formed by the persuasion technique. It can be concluded that the persuasion technique has a positive effect on the speaking skill attitude.

No significant difference was found on speaking skill attitude between genders.

In this study, it was concluded that the persuasion technique affects the speaking skill attitude positively. Displaying sensitivity to the persuasion technique will help students improve other skills. As a result, it will lead them to grow up as people with high self-confidence and to be successful in the communication. 